\title{
Performance and Volatility of Oil and Gas Stocks: A Comparative Study on Selected O\&G Companies
}

\author{
Shaharudin, Roselee S (Corresponding author) \\ Faculty of Business and Accountancy, University of Malaya \\ Tel: 60-3-7967-3955 E-mail: roseleeshah@um.edu.my \\ Samad, Fazilah \\ Faculty of Business and Accountancy, University of Malaya \\ Bhat, Sonal \\ Faculty of Business and Accountancy, University of Malaya
}

\begin{abstract}
This paper examines the effect of oil prices movements on the stock price of Oil and Gas companies in three different markets (US, India ad UK). Using daily data; the dynamic interaction between oil prices and stock prices is investigated in the presence of economic variables like interest rates and industrial productions. The results suggest that there exists significant short run and long run relationship between oil price and the oil stocks including the effect of the other variables such as interest rate and the stock index. The oil price volatility transmission has a persistent effect on the volatility of the stocks of the oil companies in all the countries that were studied.
\end{abstract}

Keywords: Oil, Volatility Determinant, Transmission \& Risk Management

\section{Introduction}

The stock markets have certainly taken a hit from the latest surge in oil prices; oil prices affect the companies' earnings and their bottom lines, which in turn affect their dividends, retained earnings, and the prices of their stocks. This is the reason that a large literature is devoted to the study of energy and its effects on macro-economic variables such as economic stability, economic growth, and international debt. For example, Hamilton (1983) studies the relationship between oil price and the Gross National Product (GNP). He concluded that increase in oil prices is responsible for decline in real GNP. Gilbert and Mork (1984) modeled the macro effects of an oil supply disruption and survey alternative policy options for dealing with the problem. Mork, Olsen, and Mysen (1994) assert that "the negative correlation between oil prices and real output seems, by now, to have been accepted as an empirical fact." In addition to the extensive investigation of the macroeconomics of energy issues, large research has been devoted to the repercussions of energy shocks on financial markets. Investigations by Charles Jones and Gautam Kaul (1996) using on reaction of the US and Canadian stock market to oil shocks show that stock prices rationally reflect the impact of news on current and future cash flows and there are no evidences of overreaction, while stock market in Japan and United Kingdom are different. However, there are very few studies that examine the relationship between oil price and the stock prices of the oil industries. One among them is a study by Huang, Masulis and Stoll (1996) who have examined the link between daily oil future returns and daily United States stock returns. Also, Al-Mudhaf and Goodwin (1993) examined the returns from 29 oil companies listed on the New York Stock Exchange. Not surprisingly, most of them are limited only to United States.

"Does the performance and volatility of oil stocks vary with respect to the changes in oil prices?" This paper looks at the relationship between the oil prices and the stocks of oil companies in three different countries. The objective is to examine the effects of oil prices on the oil stocks in different countries, whether there are long-run relationships or co-movements among the oil prices and oil industry's stock. Specifically, the dynamic interaction between oil prices and stock prices is investigated in the presence of economic variables like interest rates and industrial productions. This paper will also concentrate on the effects of volatility of crude oil prices on the oil stocks using daily data. The scope of this study extends to six oil companies from three different countries that are geographically apart and have different economic conditions; two each listed on New York Stock Exchange, London Stock Exchange and National Stock Exchange of India respectively. The results of the study should be useful to the various oil companies who are engaged in different phases of this industry and whose shares are traded on those stock exchanges. They should be of interest to the individual investors, policy makers, hedgers, arbitrageurs who buy the shares of these companies and analysts who 
wish to understand how the stocks of the different companies react to changes in the level and volatility of the oil prices.

\section{Effect of Oil Prices on Oil Stocks}

Researchers in International Finance have focused on the sensitivity of the world's oil industry stocks and oil-sensitive industries stock to the oil price growth. Some researchers (e.g., Strong, 1991) have examined how well investors are able to hedge oil price risk using oil equity portfolios. Others, such as Miller and Upton (1985a, 1985b) and Crain and Jamal (1991), have investigated how well Hotelling's valuation principle applies to oil and gas companies. Malliaris and Urrutia (1995) provided evidence of a negative reaction of share prices to the Persian Gulf crisis. Nandha and Faff (2007) examined whether and to what extent the adverse effect of oil price shocks impacts stock market returns. They analyzed 35 DataStream global industry indices for the period from April 1983 to September 2005. Their results show that oil price rises have a negative impact on equity returns for all sectors except mining, and oil and gas industries.

Hamilton (1983, 1986) conducted detailed analysis on oil price changes in US and concluded that particular timing of changes in the nominal crude oil prices reflects largely exogenous developments specifically to petroleum sector. Jimmy and Albert (1984) studied the economic performance of 4 major oil (Exxon, Mobil, Texaco, Standard Oil of California) and 4 major automobile companies in the US for the period 1970-1979, when oil prices were rising rapidly. They measured the compound yields and risk-adjusted yields on common stock for equity performance. Their results show that Oil firms' compound yields were higher than auto firms' and world oil prices were significantly related to changes in shareholders' wealth. US gasoline prices, the indicator of which most consumers are aware, did not satisfactorily explain the yields of either oil or auto firms. The impact of world oil spot prices was not significantly impounded in general yield proxies such as value weighted stock market or Treasury bill yields. In another industry focused study, Faff and Brailsford (1999) investigated the sensitivity of Australian industry equity returns to an oil price factor over the period 1983-1996. They report significant positive oil price sensitivity of Australian oil and gas, and diversified resources industries. In contrast, industries like paper and packaging, banks and transport appear to demonstrate significant negative sensitivity to oil price hikes. A firm-specific study by Al-Mudhaf and Goodwin (1993) examines the returns from 29 oil companies listed on the New York Stock Exchange. Their findings suggest a positive impact of oil price shocks on ex post returns for firms with significant assets in domestic oil production. Huang et al. (1996) conclude that the returns of the petroleum stock index and the three oil stocks (Chevron, Exxon and Mobil) are significantly correlated with current and lag one oil futures returns.

Sardosky (2001) used a multifactor market model to estimate the expected returns to Canadian oil and gas industry stock prices. Results show that exchange rates, crude oil prices and interest rates each have large and significant impacts on stock price returns in the Canadian oil and gas industry. In particular, an increase in the market or oil price factor increases the return to Canadian oil and gas stock prices while an increase in exchange rates or the term premium decreases the return to Canadian oil and gas stock prices. Hammoudeh, Dibooglu and Aleisa (2002) studied the relationships among U.S. oil prices and oil industry equity indices. Their study reports that oil price systems have a few numbers of common trends, suggesting little potential for long-run portfolio diversification. On a daily basis, none of the oil industry stock indices explains the future movements of the NYMEX oil futures prices, while these prices can explain the movements of independent oil companies engaged in exploration, refining, and marketing, confirming our results that the oil exploration companies and refiners take their cues from the oil market. Boyer and Filion (2007) use a multifactor framework to analyse the determinants of Canadian oil and gas stock returns. They find a positive association between energy stock returns and appreciation of oil and gas prices, with growth in internal cash flows and proven reserves, and negative association with interest rates. In addition, production volume and a weakening of the Canadian dollar against the US dollar have a negative impact. Finally, they found that the influence of the exchange rate, the market return and prices of natural gas on Canadian oil and gas stocks changes significantly over the years 1995-1998 and 2000-2002.

Further, Hammoudeh and Eleisa (2004) consider five oil-exporting countries, Bahrain, Kuwait, Saudi Arabia, and the UAE. In their study only the Saudi Arabian stock market exhibits some dependence on oil prices; the smaller Gulf stock markets are apparently invariant to oil price changes. In some studies, oil price sensitivity is investigated at the sector or industry level. Hammoudeh and Li (2004), using an international factor model, conclude that both world market integration and oil prices are significant determinants of stock prices at country and industry levels. Scholtens and Wang (2008) on the other hand assessed the oil price sensitivities and oil risk premiums of oil and gas firms listed on the NYSE by using two-step regression analysis using two different arbitrage pricing models. They found that the returns of oil stocks are positively associated with the returns of the stock market, the increase of spot crude oil prices and negatively with the firm's book-to-market ratio. Thus, based on the above studies, the first hypothesis for study is stated as follows:

\section{$H_{1}$ : Oil prices influence the oil stocks}




\subsection{Effect of Interest Rates on the Oil Stocks}

The Vector Auto Regressive (VAR) model takes account of the simultaneous interaction of the time series of oil futures returns, stock returns, and t-bill returns. T-bill returns are incorporated into the VAR system to control for the effect of interest rate changes on the variables of interest -- stock returns and oil futures returns. For example, stock prices depend on expected earnings discounted to the present.

Oil price changes might affect stock prices by affecting expected earnings, but it is important to control for interest rate changes that could also affect stock prices which directly affect the discount rate on expected earnings. Also, interest rates can affect futures prices relative to cash prices through the cost-of-carry model. Earlier studies of stock returns have shown that stock returns exhibit a number of important seasonalities. These seasonalities are accounted for in the analysis by introducing dummy variables in the VAR model. Huang et al., (1996, p22) argued that "Interest rate variability is probably not as important over the one-day intervals we examine as it is for the analysis in Sims (1982), where the importance of including interest rates is stressed".

Spiro (1990) reported that a significant movement in stock prices is explained by two fundamental economic variables, GNP and the interest rates. He also adds that interest rate is most responsible for the short term volatility of stock price indices. Ferson and Harvey (1991) state that real interest rates and market return are the most important determinants in explaining the return of American petroleum shares. Sadorsky (2001) also observes that crude oil prices and market return have a positive effect on stock prices whereas a depreciation of the Canadian dollar and an increase of interest rates have a negative effect on Canadian oil and gas stocks. Sadorsky (2001) deepens his analysis of the Canadian oil and gas industry by using a model where the Toronto Stock Exchange (TSE) Oil and Gas Index is explained by the Canadian market return, crude oil prices, the Canada-US exchange rate and the short term Canadian interest rates. He finds that the four factors have an influence on Canadian energy stocks, although the first two have a much larger impact. Hondroyiannis and Papapetrou (2001) showed that real stock returns are negatively related to interest rate shocks. Thus, the second hypothesis can be written as:

\section{$\mathrm{H}_{2}$ : Interest rates have an influence on the on the oil stocks}

\subsection{Stock Index}

A stock market index is a method of measuring a section of the stock market and a broad-base index represents the performance of a whole stock market. The time series of composite stock price index is one of the best data reflecting economic conditions. The index data is used to analyze and predict the perspective of markets. Jensen and Meckling (1976), page 485 argue that "the existence of a well-organized market in which corporate claims are continuously assessed is perhaps the single most important control mechanism affecting managerial behavior in modem industrial economies". Morck et al. (1990) examine whether the stock market has an influence on investment beyond forecasting future fundamentals and they find that there is a statistically significant relation. Okyu Kwon and Jae-Suk Yang (2007) investigated the strength and the direction of information transfer in the US stock market between the composite stock price index of stock market and prices of individual stocks using the transfer entropy. The results of their study indicate that there is a stronger flow of information from the stock index to the individual stocks. Thus, the third hypothesis is stated as:

\section{$H_{3}$ : The Stock Index influences the oil stocks}

\subsection{Industrial Production}

Jones and Kaul (1992) find an effect of fuel prices on stock prices but that effect disappears when future industrial production is included in the analysis. Serletis and Shahmoradi (2005) examined the dynamic comovements of natural gas prices, industrial production, and consumer prices. Ewing and Thompson (2007) examined the empirical relationship between oil prices and several key macroeconomic variables. In particular, they investigate the cyclical comovements of crude oil prices with output, consumer prices, unemployment, and stock prices. They have reported a number of important cyclical relationships using three different time series filtering methods and their results suggest that crude oil prices are procyclical and lag industrial production. Also, that oil prices lead consumer prices. The crude oil prices lag industrial production and lead consumer prices are consistent with those reported by Serletis and Shahmoradi (2005) for natural gas prices. Koutoulas and Kryzanowski (1994) find that the pure domestic components of the interest rate structure, lagged industrial production, pure international components of the differential in the Canada/US leading indicators, and the interest rate of Euro deposits have a significant influence on Canadian oil and gas assets. On the other hand, Mittoo (1992) notes that only the 3-month Treasury-bill interest rate explains these returns.

Results reported in the abovementioned literatures suggest that higher oil prices are generally bad news for economic growth and for the stock market returns. As a consequence of the negative impact of oil price shocks on the economy and oil being a direct or indirect input for many industries, one might expect a negative impact on most of the industries except a few like oil producers and explorers. In addition, interest rates and industrial production also have and impact 
on the stock returns of any company. Thus, the third hypothesis is:

$H_{4}$ : Industrial production index has an influence on the oil stocks.

\subsection{Volatility}

Ross (1989) argues that the volatility of price changes can be an accurate measure of the rate of information flow in a financial market. It is possible that no significant lead or lag cross-correlations are observable in the returns but that price volatility - the rate of information flow - in one market leads volatility in the others. Evidence that volatility is correlated across markets would imply dependence in the information processes. The expected market risk premium (the expected return on a stock portfolio minus the Treasury bill yield) is positively related to the predictable volatility of stock returns. There is also evidence that unexpected stock market returns are negatively related to the unexpected change in the volatility of stock returns. This negative relation provides indirect evidence of a positive relation between expected risk premiums and volatility (Schwert and Stambaugh, 1987).

Hammoudeh et. al. (2002) with the autoregressive conditional heteroskedasticity (ARCH)/GARCH analysis they suggested that the oil futures market's volatility has a matching resonant or volatility-echoing effect on the stocks of the oil exploration, production, and domestic integrated companies, and a volatility-dampening effect on the stocks of oil international integrated and oil and gas refining and marketing companies. Again, Malik and Hammoudeh (2005) examined the volatility and shock transmission mechanism among US equity, global crude oil market, and equity markets of Saudi Arabia, Kuwait, and Bahrain. Their results show significant transmission among second moments. They showed that in all cases, Gulf equity markets receives volatility from the oil market but only in the case of Saudi Arabia a significant volatility spillover from the Saudi market to the oil market.

$H_{5}$ : Volatility in the crude oil prices effect the oils stocks.

\subsection{Theoretical Framework}

The basic definition of efficient market hypothesis suggests that given the assumption that relevant information is fully available to the public, all changes will immediately reflected in the stock's price. In other words, securities in an efficient market are traded and priced on the basis of all known relevant facts. If this happens, all buyers and sellers buy and sell shares on the basis of having access to full information about the securities in question. And when faced with new information whether firm specific or macroeconomics changes, some investors may over react and some may under react. However the degree of efficiency across market globally is different. This will hypothetically reflect on the speed of adjustment that each individual market will react.

[FIGURE 1]

\section{Data and Methodology}

\subsection{Data}

Three stock markets were selected: New York Stock Exchange (NYSE), London Stock Exchange (LSE) and the National Stock Exchange India (NSE). The New York Stock Exchange (NYSE) is a stock exchange based in New York City. It is the largest stock exchange in the world by dollar volume and, with 2,764 listed securities, has the second most securities of all stock exchanges. It ranks third in the world in terms of company listings with 3,200 companies. The London Stock Exchange or LSE is a stock exchange located in London, United Kingdom. Founded in 1801, it is one of the largest stock exchanges in the world, with many overseas listings as well as British companies. The LSE is part of the London Stock Exchange Group plc. NSE is a Mumbai-based stock exchange. It is the largest stock exchange in India in terms of daily turnover and number of trades, for both equities and derivative trading. Though a number of other exchanges exist, NSE and the Bombay Stock Exchange are the two most significant stock exchanges in India and between them are responsible for the vast majority of share transactions.

The six stocks of oil companies two each from the above three stock exchanges was chosen. The selection of the oil companies was based on the performance and thus those having the height Return on Equity (ROE) based on 5 years average ROE were selected. Thus, Exxon Mobil and Valero from the New York Stock Exchange, Royal Dutch Shell and Gazprom from the London Stock Exchange and Reliance Industries and Indian Oil Corporation Limited from the National Stock Exchange of India were chosen for study. The Oil prices are based on the London Brent Crude Oil Index. Brent Crude is the biggest of the many major classifications of oil consisting of Brent Crude, Brent Sweet Light Crude, Oseberg and Forties. Brent Crude is sourced from the North Sea. The Brent Crude oil marker is also known as Brent Blend, London Brent and Brent petroleum. It is used to price two thirds of the world's internationally traded crude oil supplies.

The daily interest rates and industrial productions are used as control variables in the analysis. The interest rates are based on the three month Treasury bill with respect to each stock exchange. Industrial production is an economic report that measures changes in output for the industrial sector of the economy. The industrial sector includes manufacturing, mining, and utilities. Although these sectors contribute only a small portion of GDP (Gross Domestic Product), they are 
highly sensitive to interest rates and consumer demand. This makes Industrial Production an important tool for forecasting future GDP and economic performance. All the data was obtained from DataStream, Thomson DataStream being the world's largest most respected financial statistical database. The empirical analysis has been carried out using the daily data for the period of August 08, 2003 to August 08, 2008.

\subsection{Methodology}

The Cointegration of variables will be tested using Vector Auto Regressive and Error Correction Method. Cointegration refers to linear combination of non-stationary time series that result in stationary time series in the presence of cointegration among the variables (Granger, 1986). Cointegration is a method of defining long run relationship amongst a group of time series variables (Hamilton, 1987). The variance decomposition and impulse response were employed to analyze the short-run dynamics of the variables. The volatility of oil stocks with respect to the volatility of oil prices using ARCH and GJR GARCH.

\section{Research Results}

The short run relationship between the variables is tested using the VAR model. The lag order of the VAR which is behind the cointegration analysis is been selected according to the Akaike Information Criterion (AIC). Table 1 shows the results of the unrestricted VAR for all the oil stocks. Table 1 show that the standard error of the equation provides a measure of how different the predicted values of the dependent variable are from the actual values. In general, smaller values are better because they indicate a tighter fitting model (less dispersion about the regression line). The results indicate that the Exxon Mobil stocks are influenced by both the first and second lag of oil prices, interest rates, the stock index and the Exxon Mobil stock itself. However, the Industrial production index does not significantly impact the Exxon Mobil stock prices.

\section{[TABLE 1]}

The co-efficient of the VAR model suggest that the price of the stock decreases by $0.0377 \%$ for every $1 \%$ increase in the first lagged difference of the Exxon Mobil stock prices and by $0.07 \%$ for every $1 \%$ increase in the second lagged difference of the Exxon Mobil stock prices. For every 1\% increase in the first lagged difference and second lagged difference of the NYSE, the price of Exxon Mobil stocks decrease by $0.10 \%$ and increase by $0.0913 \%$ respectively. For every $1 \%$ increase in the first lagged difference of the Oil prices, the price of Exxon Mobil stocks increase by $0.0216 \%$ and $1 \%$ increase in second lagged difference of oil prices, the Exxon Mobil stocks decrease by $0.0081 \%$. For every $1 \%$ increase in the first lagged difference and second lagged difference of the Interest rates, the price of Exxon stocks decrease by $0.0039 \%$ and $0.0018 \%$ respectively.

Identical relationship between the Chevron stocks, oil price and the other variables is seen. All the variables at their first and second difference have significant short run relationship (at 5\% and 10\% significance level) with the Chevron stocks except for the industrial production index. It should be noted that over all oil prices have positive significant impact on the US oil stocks. Industrial production index in US does not have a significant impact on the oil stock prices. However, industrial production index does have a significant impact on the Indian oil stocks (Reliance and IOCL). As in case of US oil stocks, oil stocks in UK also are influenced by all the variables except for the industrial production index. In addition the Johansen cointegration test was run (with respect to each company stocks) to test the long run relationship. The Johansen cointegration test indicated the presence of 5 cointegrating equations in the long run. The results of the test are shown in Table 2 .

\section{[TABLE 2]}

Similarly, the Johansen cointegration test indicated the presence of 5 cointegrating equations in the long run for the Indian and UK oil stocks as well.

\subsection{Vector Error Correction Model (VECM)}

The finding of the presence of cointegration sets the stage for using the error-correction model. If a set of nonstationary variables is cointegrated then an unrestricted vector autoregression model (VAR) comprised of the first differences of these variables will be misspecified. The reason is that the first differences of nonstationary variables impose too many unit roots, and information on long-run equilibrium relationships among the variables will be lost. In such a case the error-correction model (VECM) must be used. This model includes a vector of error terms that represents deviations from the long-run equilibrium and lagged short-term deviations. VECM provides information on how the dependent variable, EXXON is adjusted to restore long run equilibrium in response to the error correction term. In estimating the VECM, the lag interval was specified based on the results obtained in the VAR lag selection, this VECM is a restricted VAR with two lags. The number of cointegrating equations was specified based on the Johansen cointegration test. Table 3 presents the VECM for the stocks. In the VECM, the estimates show that the error-correction terms in the equation, which measure the long-run disequilibrium, are significantly different from zero. The addition of the error terms results in a positive value, implying that the Exxon Mobil stock prices show divergence from the equilibrium and 
that they do not have the tendency to restore back to equilibrium. The co-efficient of the error terms indicate the backward (if negative) or forward movement (if positive) towards equilibrium following a shock to the model over the respective period of time. In the long run, oil prices have significant positive impact on the oil stocks, while the interest rates and NYSE influence negatively, the relationship with industrial production index however is not significant. For every $1 \%$ increase in the first lag of the Exxon Stocks, the price of Exxon Mobil stocks decrease by $0.0281 \%$. If the first lag of the interest rates increase and NYSE by $1 \%$, the stock price decreases by $0.007 \%$ and $0.114 \%$ respectively. However, oil prices have positive effect on the oil stocks; increase in oil prices by $1 \%$ would increase the stock prices by $0.0138 \%$.

\section{[TABLE 3]}

Long run relationship using vector error correction was also tested for oil stocks picked from India and UK. Incase of Reliance Industries, the sum of error terms is positive indicating divergence from equilibrium. However, for IOCL stocks, the error terms sum up to negative number, showing that the stocks have a tendency to converge to equilibrium. All the variables, including industrial production index have a significant long run relationship with the oil prices and oil price negatively affect the oil stocks in India. For stocks of Shell and Gazprom, the error correction term is positive. Here, we see that stocks of both the companies like most of the other stocks in this study show divergence from equilibrium. The results are similar to that of oil stocks in US, all the variables show long run relationship except for industrial production index. Also, mixed behavior of oil stocks is seen under the influence of oil prices.

\subsection{Variance Decomposition and Impulse Response}

Next, the generalized variance decomposition and the generalized impulse response functions are employed to analyze the short-run dynamics of the variables. The purpose of the investigation is to find how oil stock prices respond to shocks by the other variables of the system. The generalized impulse responses provide an estimate of the response of a variable in the case of innovation in another variable.

The analysis of variance decomposition on Exxon Mobil as per table 4 tends to suggest that each of the variables used in the empirical analysis can be explained by the disturbances in the other variables. Specifically, in the short-run period more than $99 \%$ of the variability in the stocks of Exxon Mobil changes is explained by its own innovations, Next, NYSE and industrial production index contribute to $0.4 \%$ and $0.2 \%$ respectively variations in the Exxon Mobil stock prices, while $0.06 \%$ of the variability in the stock price is explained by innovations in the price of oil and a very minimal effect of interest rates affect the Exxon Mobil stocks.

\section{[TABLE 4]}

The results of variance decomposition for Chevron stocks are shown in Table 5. In short-run period more than 96\% of the variability in the stocks of Chevron stocks changes is explained by its own innovations. Chevron stocks are affected by NYSE (more than $2 \%$ ), and then by oil price $(0.4 \%)$, interest rates $(0.18 \%)$ and industrial production index $(0.03 \%)$. Unlike Exxon Mobil stocks, Chevron stocks are affected quiet significantly by interest rates.

\section{[TABLE 5]}

Table 6 shows the results of variance decomposition for Reliance stocks. In short-run period almost $99 \%$ of the variability in the stocks of Reliance stocks changes is explained by its own innovations. Reliance stocks are affected by interest rates $(0.44 \%)$, then by industrial production $(0.23 \%)$, oil price $(0.18 \%)$ and NSE $(0.07 \%)$.

\section{[TABLE 6]}

Table 7 shows the results of variance decomposition for IOCL stocks. In short-run period more than $98 \%$ of the variability in the stocks of IOCL stocks changes is explained by its own innovations. $0.8 \%$ of variability in IOCL stocks is explained by oil prices, $06 \%$ by NSE, $0.09 \%$ by interest rates and a minimal $0.015 \%$ by the industrial production index.

\section{[TABLE 7]}

Table 8 shows the results of variance decomposition for stocks of Royal Dutch Shell. In short-run period more than $99 \%$ of the variability in the stocks of Shell is explained by its own innovations. More than $0.1 \%$ of variability in Shell stocks is explained by oil prices, $04 \%$ by LSE, $0.42 \%$ by interest rates and a minimal $0.015 \%$ by the industrial production index.

\section{[TABLE 8]}

Table 9 shows the results of variance decomposition for stocks of Gazprom. In short-run period more than $99 \%$ of the variability in the stocks of Shell is explained by its own innovations. More than $0.1 \%$ of variability in Shell stocks is explained by oil prices, $047 \%$ by LSE, $0.4 \%$ by interest rates and a minimal $0.05 \%$ by the industrial production index.

[TABLE 9] 
Figure 2 below shows the impulse response of all the stocks. It can be seen from the graph that the Exxon Mobil stocks restore back to equilibrium in 3 days after any shock in oil prices. Similarly, for any shocks in interest rates and the stock index, the Exxon Mobil stock prices come back to equilibrium in five to ten days. However, shocks from industrial production take a longer period to stabilize. The Chevron stocks restore back to equilibrium in 4 days after any shock in oil prices. Similarly, for any shocks in interest rates and the stock index, the Exxon Mobil stock prices come back to equilibrium in five to ten days. It is evident from the graph that the Reliance stock restore back to equilibrium within 4 days from most of the shocks, however, shocks by interest take up to 8 days for recovery. It is evident from the graph that IOCL stocks restore back to equilibrium within 4-5 days from most of the shocks. For Shell, it took 5-6 days for the stock to restore back to equilibrium. The response of Gazprom the stocks restore back to equilibrium within 5-6 days from most of the shocks.

\section{[FIGURE 2]}

\subsection{Volatility}

The LM tests for all the oil stocks (individually) and oil price indicate that the ARCH effects are significant at the 1\% level, suggesting the use of the ARCH/GARCH methodology is warranted (see Table 10).

\section{[TABLE 10]}

Based on the methodology, the volatility of oil prices coming on the oil stocks was examined using the GJR GARCH model. From the Q-Q plots it was seen that the time series data for oil price and all the oil stocks was not normal and hence, Student's t distribution was used in the estimation of GARCH model. The estimates of the GJR GARCH model for the oil stocks and oil prices are provided in Table 11.

\section{[TABLE 11]}

The four coefficients in the variance equation are listed as $\mathrm{C}$, the intercept; $\mathrm{ARCH}$ (1), the first lag of the squared return; the dummy variable and GARCH (1), the first lag of the conditional variance. The ARCH term is significant while the GARCH term is not significant. This entails that, the long term moving average volatility of oil prices has an impact on the oil stocks while the short term volatility does not significantly affect the oil stocks. Notice that the coefficients sum up to a number less than one, which is required to have a mean reverting variance process. Since the sum is very close to one, the volatility has quiet persistent shocks. The dummy term is not significant which implies that the oil shocks to the oil stocks are positive. In addition, the sum of the co-efficient of the error term and the dummy variable is greater than zero, which implies that any bad news increases volatility and its effects.

\section{Summary of Results}

The overall results suggest that there exists co-integration between oil stocks, oil prices, interest rates, industrial production and the stock index and there is a significant short term as well as long term relationship between them. It was seen that oil prices affect the oil stocks and this relation is influenced by the stock index and interest rates. Thus, the hypotheses $\mathrm{H}_{1}$ through $\mathrm{H}_{3}$ are accepted. The influence of the industrial production index could not be warranted as it is not significant in case of US and UK, while in India the effect is significant. Hence, hypothesis $\mathrm{H}_{4}$ is indecisive. The results of variance decomposition implies that oil prices account to $0.1 \%$ to $0.9 \%$ variance in the oil stocks depending on the extent of the effect of other variables. The impulse response function suggest that the in the short run, the oil stocks recover from most of the shocks from the variables in a period of 4-8 days. From the GARCH results it is clear that volatility shocks of oil prices on the oil stocks are quite persistent and that long-run average shocks are more influential than the immediate volatility shocks.

\subsection{Conclusion and Recommendations}

This study investigates the effects of oil prices on oil stocks of three different markets (US, India ad UK) using daily data for the available period August 08, 2003 to August 08, 2008. The oil price is the London Brent Crude Oil Index. The oil stocks include the Exxon Mobil and Chevron stocks from the New York Stock Exchange, Reliance Industries and Indian Oil Corporation Limited stocks from the National Stock Exchange of India, and Royal Dutch Shell and Gazprom stocks from the London Stock Exchange.

The empirical investigation employs unit root tests, cointegration tests, variance auto regression, error-correction models with variance decomposition and impulse response, and ARCH/GARCH models. The cointegration tests for the variables (oil price, stock price, stock index, interest rates and industrial production index) system indicate that these variables have long-run relationship and have five cointegrating relationship. Moreover, the VAR and VECM for the system suggest that there exists significant short run and long run relationship between oil price and the oil stocks including the effect of the other variables such as interest rate and the stock index. According to the estimated coefficients of the structural part of the model it is noted that oil prices in US have a positive impact on the oil stocks. The results in for US oil stocks are in agreement with those achieved by Nandha and Raff (2007) which say that oil price rises have positive impact on the equity returns of oil and gas companies. 
In case of Indian oil stocks the impact of oil price is negative, while in case of UK, the impact is mixed, negative for Royal Dutch Shell and positive in case of Gazprom. One way to explain the variation in these results would be based on the oil reserves owned by these countries. The Oil \& Gas Journal, Vol. 103, No. 47 (Dec. 19, 2005) estimated the US has oil reserves of 21.4 billion barrels while India has only 5.8 billion barrels. Thus, increase in oil price is good news to US and not for India. Accordingly, after acquisition of the oil company Sibneft, Gazprom, with 119 billion barrels $(1.89 \times 1010 \mathrm{~m} 3)$ of reserves, ranks behind only Saudi Arabia, with 263 billion barrels $(4.18 \times 1010 \mathrm{~m} 3)$ and this explain the positive relationship of its stocks with the increase in oil price while this is not the case with Shell. The industrial production index except for India does not have any influence on the stock prices. The effect of interest rates on the stocks prices of the oil companies can relate to the D/E ratio of the company. It was seen that the D/E ratio for Exxon Mobil, Chevron, Reliance and IOCL was over 0.5 and they have a negative impact of the interest rates. While, Royal Dutch Shell and Gazprom have a debt to equity ratio (D/E) of less than 0.4 and are positively related with interest rates. If the oil company has high liability the effect on its stock is negative and vise versa. Cassar, Gavin John (2005) explains financing-investment linkages play an important role in both the future operating performance of firms and how the market prices the firm.

The variance decomposition and impulse response analysis suggests the existence of instantaneous, temporary effect of oil price innovations on the oil stock prices. However, the effects of all the variables vary with each company. The impulse response function also indicates that the UK (London) market is more efficient than the other markets under study. The volatility analysis using GJR GARCH for the oil stocks suggests that the oil price volatility transmission has a persistent effect on the volatility of the stocks of the oil companies in all the countries studied here. It also implies that oil volatility effects of higher oil prices are more than that during the low oil prices. These results are similar to that obtained by Hammoudeh, Dibooglu and Aleisa (2002) where the studies the relationship between the oil price and oil equity indices in US. It was also observed historical prices to be responsible for more volatility transmission than the spot price.

\subsection{Suggestions for Future Research}

This study can be extended further by considering more oil companies in each stock exchange and also including other important countries. By doing so, the results obtained will be more generalized. It is also evident that there is no simple correlation between crude oil price and oil stocks. The complexities brought on by vertical integration, multinational organization and the regulatory climate should also be considered for the analysis.

\subsection{Implication}

This paper contributes to the knowledge of the dynamic relationships between oil stock and oil prices, including other macro-economic variables and stock index. The results highlight the varying significance of the variables in explaining the stock prices in the markets. The results of the study should be useful to the various oil companies who are engaged in different phases of this industry and whose shares are traded on those stock exchanges. For the oil companies, they can adjust their liabilities knowing the effect of interest rates on their stocks. The oil companies can also study their comovement with the market. With this they can track the systemetic risk the company hold and can adjust their beta. The results should also be useful to the individual investors, hedgers, and arbitrageurs who buy the shares of these companies and wish to understand how the stocks of the different companies react to changes in the level and volatility of the oil spot/futures prices. If an increase in the oil price leads to a decrease in the stock prices, this increase should be a precursor for the investors to avoid these stocks. Moreover, the presence of long-run relationships among the oil prices, oil stocks and other macro-economic variables also throws light on having these oil stocks in the portfolio in the long run taking the economic condition into account. The impulse response analysis for various stocks also throws light on the efficiency of the markets in response to shocks. Thus, investors can decide on the market they wish to invest based on their efficiency. The policy implication for oil volatility transmission is that, at times of oil volatility, traders should choose the oil company stocks that match their tolerance for volatility and use the right financial derivative to profit from this volatility.

\section{Limitations}

This study was intended to become a preliminary prior to analyze thirty oil companies listed on all the major stock exchanges across the world. It covers six oil and gas companies (two each from the three stock exchanges mentioned above). Only two macro-economic factors are included i.e. the industrial productions and interest rates as controlling variables even though we believed that there might be other factors that could influence the findings. Future research is necessary to determine other potential macro-economic variables.

\section{References}

Abugri, Benjamin A. (2008). Empirical relationship between macroeconomic variables and stock returns: Evidence from Latin America. International Review of Financial Analysis, 17, 396-410. 
Aktham Maghyereh and Al-Khandari, Ahmad. (2007). Oil prices and stock markets in GCC countries: new evidence from non-linear cointegration. Journal of Managerial Finance, 33 (7), 449-460.

Cologni, A, Manera, M. (2008). Oil prices, inflation and interest rates in a structural cointegrated VAR model for the G-7 countries. Energy Economics, 30, 856-888.

Al-Mudaf, Anwar, A, Goodwin, Thomas H. (1993). Oil shocks and Oil stocks: an evidence from 1970s. Applied Economics, 25, 181-190.

Hayo,B, Kutan, A. (2005). The impact of news, oil prices, and global market developments on Russian financial markets. Economics of Transition, Volume 13 (2), 373-393.

Boyer, Martin M. and Filion, Didier. (2009). Common and fundamental factors in stock returns of Canadian oil and gas companies. Energy Economics, 29, 428-453.

Buono, Mark J. (1989). The relationship between the variability of inflation and the stock returns: An empirical investigation. The Journal of Financial Research, 12 (4), 329-339.

Papapetrou, E. (2001). Oil price shocks, stock market, economic activity and employment in Greece. Energy Economics, 23, 511-532.

Ewing, Bradley T. \& Thompson, Mark A. (2007). Dynamic cyclical co movements of oil price with industrial production, consumer price, unemployment and stock prices. Energy Policy, 35, 5535-5540.

Faff, Robert, Mohan, N. (2008). Does oil move equity prices? A global view. Energy Economics, 30, $986-997$.

Farooq Malik, T. and Hammoudeh,S. (2007). Shock and volatility transmission in the oil, US and Gulf equity markets. International Review of Economics and Finance, 16, 357-368.

Gallegati, M. (2008). Wavelet analysis of stock returns and aggregate economic activity. Journal of Computational Statistics and Data Analysis, 52, 3061-3074.

Hondroyiannis, G. \& Papapetrou, E. (2001). Macroeconomic influences on the stock market. Journal of Economics and Finance, 25 (1), 33-49.

Hammoudeh, S. \& Huimin, L. (2005). Oil sensitivity and systematic risk in oil sensitive market, Journal of Economics and Business. 57, 1-21.

Hammoudeh, S., Dibooglu, S. and Aleisa, E. (2004), Relationship among US oil prices and oil industry equity indices, International Review of Economics and Finance. 13, 427-453.

Henriques, I. \& Sadorsky,P. (2008), Oil price and stock price of alternative energy companies. Energy Economics, 30, 998-1010.

Huang, R. D., Masulis, R. W. and Stoll, H. R. (1996). Energy Shocks and Financial Markets. Journal of Futures Markets 16(1): 1-27.

Jones, C.M., Kaul, G. (1996). Oil and the stock markets. Journal of Finance, 51(2), 463-491.

Miller, M. and Upton, C. (1985a). A test of the Hotelling Valuation Principle. Journal of Political Economy. (Feb), $1-25$.

Miller, M. and Upton, C., (1985b). The pricing of oil and gas: Some further results. The Journal of Finance, (Jul), 1009-1018.

Park, J. \& Ratti,R. (2008). Oil price shocks and stock markets in the U.S. and 13European countries. Energy Economic, 30 (5), 2587-2608.

Narayan, P.K., Narayan, S. (2007). Modelling oil price volatility. Energy Economics, 35, 6549-6533.

Roger D. Huang, R. D., Masulis,D.W and Stoll,H.R. (1996). Energy shocks and financial markets. Journal of Futures Markets. 16(1), 1-27.

Lardic, S., Mignon,V. (2006). The impact of oil prices on GDP in European countries: An empirical investigation based on asymmetric cointegration. Energy Policy, 34, 3910-3915.

Perry, S. (2001). Risk factors in stock returns of Canadian oil and gas companies. Energy Economics, 23, 17-28.

Scholtens, B., and Wang, Lei (2008). Oil risks in oil stocks. The Energy Journal, 29, 89-112.

Smith, R.T., Bradley, M. and Greg,J.1. (1986). Studying firm-specific effects of regulation with stock market data: an application to oil price regulation. Rand Journal of Economics, 17 (4), 467-489.

Spiro, P.S. (1990). The impact of interest rate changes on stock price Volatility. Journal of Portfolio Management, 16 (2), pg. 63-68.

Strong, J.S. (1991). Using Oil Share Portfolios to Hedge Oil Price Risk, Quarterly Review of Economics and Business. 31, 48-63.

Waff, R.W. and Brailsford, T.J. (1999), Oil price risk and Australian stock market. Journal of Energy Finance and Development, 4, 69-87.

Huang, Y. and Guo,F. (2007). The role of oil price shocks on China's real exchange rate. China Economic Review, 18, 403-416.

Zhang, D. (2008). Oil shock and economic growth in Japan: A nonlinear approach. Energy Economics. 30 (5) 23742390 . 


\section{Appendixes}

Table 1. Unrestricted Var on O\&G Stocks

\begin{tabular}{lllllll}
\hline Variables & Exxon Mobil & Chevron & $\begin{array}{l}\text { Reliance } \\
\text { Industries }\end{array}$ & Indian Oil & $\begin{array}{l}\text { Royal Dutch } \\
\text { Shell }\end{array}$ & Gazprom \\
\hline Stock (-1) & -0.037781 & -0.145776 & 0.033633 & 0.142511 & -0.014597 & 0.036855 \\
Stock (-2) & -0.070088 & -0.085133 & 0.034315 & -0.038403 & 0.084724 & -0.032582 \\
Stock Index (-1) & -0.100694 & 0.360543 & 0.017396 & 0.151595 & -0.000962 & -0.000148 \\
Stock Index (-2) & 0.091261 & 0.282498 & -0.059029 & 0.282498 & -0.000345 & 0.001890 \\
Oil Price (-1) & 0.021586 & 0.023186 & -0.061513 & -0.159796 & -0.026152 & 0.007508 \\
Oil Price (-2) & -0.008140 & 0.092351 & -0.006317 & 0.059803 & -0.008814 & 0.068050 \\
Int. Rates (-1) & -0.003986 & -0.063896 & -0.130785 & -0.070665 & 0.218664 & 0.307284 \\
Int. Rates (-2) & -0.001775 & 0.037204 & 0.006888 & 0.027659 & -0.015141 & -0.229933 \\
Ind. Prod. (-1) & Not Sig. & Not Sig. & 0.029760 & -0.010354 & Not Sig. & Not Sig. \\
Ind. Prod. (-2) & Not Sig. & Not Sig. & 0.044845 & 0.007859 & Not Sig. & Not Sig. \\
C & 0.000706 & 0.000506 & 0.001921 & 0.000147 & 0.000221 & 0.001199 \\
S. E. Equation & 0.013109 & 0.020209 & 0.022850 & 0.026508 & 0.013438 & 0.024338 \\
\hline
\end{tabular}

Table 2. Unrestricted Cointegration Rank Test for Exxon Mobil Stocks

\begin{tabular}{lcccc}
\hline $\begin{array}{l}\text { Hypothesized } \\
\text { No. of CE(s) }\end{array}$ & Eigenvalue & Statistic & $\begin{array}{l}\text { 5 Percent } \\
\text { Critical Value }\end{array}$ & $\begin{array}{l}\text { Critical Value } \\
\text { Cricent }\end{array}$ \\
\hline None ** & 0.340135 & 1799.941 & 68.52 & 76.07 \\
At most 1** & 0.315134 & 1258.675 & 47.21 & 54.46 \\
At most 2** & 0.256429 & 765.8253 & 29.68 & 35.65 \\
At most 3** & 0.224518 & 380.0536 & 15.41 & 20.04 \\
At most 4** & 0.036930 & 48.99378 & 3.76 & 6.65 \\
\hline
\end{tabular}

*(**) denotes rejection of the hypothesis at the $5 \%(1 \%)$ level

Trace test indicates 5 cointegrating equation(s) at both $5 \%$ and $1 \%$ levels

Table 3. Results of Vector Error Correction Model

\begin{tabular}{llllllc}
\hline $\begin{array}{l}\text { Variables } \\
\text { Error Correction }\end{array}$ & Exxon Mobil & Chevron & $\begin{array}{l}\text { Reliance } \\
\text { Industries }\end{array}$ & Indian Oil & $\begin{array}{l}\text { Royal Dutch } \\
\text { Shell }\end{array}$ & Gazprom \\
\hline ECT1 & $-0.016485^{*}$ & $-0.066536^{* *}$ & $-0.002580^{*}$ & $-0.020353^{*}$ & $-0.015848^{*}$ & $-0.004004^{*}$ \\
ECT2 & $0.026571^{* *}$ & $0.044106^{* * *}$ & $-0.001285^{*}$ & $-0.005019^{*}$ & $0.002349^{*}$ & $0.005332^{*}$ \\
ECT3 & $0.001549^{*}$ & $-0.008475^{*}$ & $0.000645^{*}$ & $0.003454^{*}$ & $0.001734^{*}$ & $0.005026^{*}$ \\
ECT4 & $0.015319^{*}$ & $0.083252^{* *}$ & $0.012763^{* *}$ & $0.008572^{*}$ & $0.012232^{*}$ & $-0.011017^{*}$ \\
Stock (-1) & $-0.028572^{* *}$ & $-0.093057^{* *}$ & $0.035799^{* *}$ & $0.146869^{* *}$ & $-0.011910^{* *}$ & $0.030222^{* *}$ \\
Stock Index (-1) & $-0.114773^{* *}$ & $0.261799^{* * *}$ & $0.013113^{* * *}$ & $0.135063 * *$ & $-0.001792^{*}$ & $-0.002686^{*}$ \\
Oil Price (-1) & $0.013854^{* *}$ & $0.014667^{*} *$ & $-0.061013^{* *}$ & $-0.139311^{* *}$ & $-0.004739^{* *}$ & $0.005510^{* *}$ \\
Int. Rates (-1) & $-0.007544^{* *}$ & $-0.055539^{* *}$ & $-0.134683^{* * *}$ & $-0.085721^{* * *}$ & $0.204060^{* * *}$ & 0.295498 \\
Ind. Prod. (-1) & Not Sig. & Not Sig. & $0.031770^{* *}$ & $-0.016169^{* *}$ & Not Sig. & Not Sig. \\
C & 0.000686 & 0.000700 & 0.001918 & 0.000231 & 0.001918 & 0.001158 \\
Log Likelihood & 3810.378 & 3248.423 & 3083.791 & 2896.642 & 3776.331 & 3002.416 \\
Akaike & -5.828800 & -4.966907 & -4.714404 & -4.427365 & -5.776582 & -4.589594 \\
Schwarz Criteria & -5.789128 & -4.927235 & -4.674732 & -4.387693 & -5.736910 & -4.549923 \\
\hline
\end{tabular}

* Significant at the $1 \%$ level. **Significant at the $5 \%$ level., ***Significant at the $10 \%$ level. 
Table 4. Variance decomposition analysis of Exxon Mobil Stocks

\begin{tabular}{lccccc}
\hline Period & $\begin{array}{l}\text { Exxon } \\
\text { Stocks }\end{array}$ & $\begin{array}{r}\text { Mobil Industrial } \\
\text { Production }\end{array}$ & Interest Rates & NYSE & Oil Price \\
\hline 1 & 100.0000 & 0.000000 & 0.000000 & 0.000000 & 0.000000 \\
2 & 99.61699 & 0.084124 & 0.000746 & 0.242096 & 0.056045 \\
3 & 99.40715 & 0.116843 & 0.000880 & 0.414438 & 0.060689 \\
4 & 99.37416 & 0.146580 & 0.001135 & 0.415490 & 0.062635 \\
5 & 99.35638 & 0.163551 & 0.001512 & 0.415665 & 0.062892 \\
6 & 99.34024 & 0.179486 & 0.001520 & 0.415843 & 0.062915 \\
7 & 99.32705 & 0.192688 & 0.001535 & 0.415808 & 0.062925 \\
8 & 99.31588 & 0.203828 & 0.001556 & 0.415797 & 0.062939 \\
9 & 99.30625 & 0.213439 & 0.001569 & 0.415795 & 0.062949 \\
10 & 99.29799 & 0.221679 & 0.001581 & 0.415792 & 0.062957 \\
\hline
\end{tabular}

Table 5. Variance decomposition analysis of Chevron Stocks

\begin{tabular}{llcccc}
\hline Period & Chevron Stocks & $\begin{array}{l}\text { Industrial } \\
\text { Production }\end{array}$ & Interest Rates & NYSE & Oil Price \\
\hline 1 & 100.0000 & 0.000000 & 0.000000 & 0.000000 & 0.000000 \\
2 & 97.68585 & 0.029788 & 0.116766 & 2.137656 & 0.029937 \\
3 & 96.70228 & 0.030413 & 0.169100 & 2.688601 & 0.409603 \\
4 & 96.59847 & 0.030871 & 0.176496 & 2.783547 & 0.410621 \\
5 & 96.58421 & 0.032209 & 0.181532 & 2.787244 & 0.414804 \\
6 & 96.58086 & 0.033234 & 0.182652 & 2.788270 & 0.414983 \\
7 & 96.58034 & 0.033581 & 0.182667 & 2.788321 & 0.415092 \\
8 & 96.57991 & 0.033967 & 0.182725 & 2.788308 & 0.415095 \\
9 & 96.57952 & 0.034347 & 0.182724 & 2.788315 & 0.415094 \\
10 & 96.57922 & 0.034650 & 0.182724 & 2.788310 & 0.415094 \\
\hline
\end{tabular}

Table 6. Variance decomposition analysis of Reliance Industries Stocks

\begin{tabular}{lccccc}
\hline Period & $\begin{array}{l}\text { Reliance } \\
\text { Stocks }\end{array}$ & Ind. Oil Price & NSE & Interest Rates & $\begin{array}{l}\text { Industrial } \\
\text { Production }\end{array}$ \\
\hline 1 & 100.0000 & 0.000000 & 0.000000 & 0.000000 & 0.000000 \\
2 & 99.35354 & 0.172656 & 0.007670 & 0.402088 & 0.064050 \\
3 & 99.08097 & 0.177713 & 0.076668 & 0.431928 & 0.232721 \\
4 & 99.07331 & 0.177700 & 0.076683 & 0.439489 & 0.232821 \\
5 & 99.07085 & 0.177798 & 0.077083 & 0.441450 & 0.232820 \\
6 & 99.07043 & 0.177801 & 0.077092 & 0.441852 & 0.232830 \\
7 & 99.07034 & 0.177801 & 0.077092 & 0.441934 & 0.232830 \\
8 & 99.07033 & 0.177801 & 0.077092 & 0.441951 & 0.232831 \\
9 & 99.07032 & 0.177801 & 0.077092 & 0.441955 & 0.232831 \\
10 & 99.07032 & 0.177801 & 0.077092 & 0.441956 & 0.232831 \\
\hline
\end{tabular}

Table 7. Variance decomposition analysis of IOCL Stocks

\begin{tabular}{llllcc}
\hline Period & IOCL Stocks & Oil Price & NSE & Interest Rates & $\begin{array}{l}\text { Industrial } \\
\text { Production }\end{array}$ \\
\hline 1 & 100.0000 & 0.000000 & 0.000000 & 0.000000 & 0.000000 \\
2 & 98.52072 & 0.811767 & 0.577281 & 0.084735 & 0.005492 \\
3 & 98.48235 & 0.812676 & 0.599983 & 0.090118 & 0.014874 \\
4 & 98.47521 & 0.818083 & 0.600857 & 0.090729 & 0.015123 \\
5 & 98.47471 & 0.818378 & 0.600913 & 0.090801 & 0.015194 \\
6 & 98.47465 & 0.818378 & 0.600925 & 0.090833 & 0.015211 \\
7 & 98.47464 & 0.818382 & 0.600925 & 0.090843 & 0.015214 \\
8 & 98.47463 & 0.818382 & 0.600926 & 0.090845 & 0.015214 \\
9 & 98.47463 & 0.818382 & 0.600926 & 0.090846 & 0.015214 \\
10 & 98.47463 & 0.818382 & 0.600926 & 0.090846 & 0.015214 \\
\hline
\end{tabular}


Table 8. Variance decomposition analysis of Royal Dutch Shell Stocks

\begin{tabular}{|c|c|c|c|c|c|}
\hline Period & $\begin{array}{l}\text { Royal } \\
\text { Shell Stock }\end{array}$ & $\begin{array}{l}\text { Dutch Oil Price } \\
\text { ss }\end{array}$ & LSE & Interest Rates & $\begin{array}{l}\text { Industrial } \\
\text { Production }\end{array}$ \\
\hline 1 & 100.0000 & 0.000000 & 0.000000 & 0.000000 & 0.000000 \\
\hline 2 & 99.44573 & 0.083652 & 0.039557 & 0.418462 & 0.012599 \\
\hline 3 & 99.41445 & 0.108288 & 0.043695 & 0.418344 & 0.015220 \\
\hline 4 & 99.41010 & 0.110768 & 0.043829 & 0.419883 & 0.015415 \\
\hline 5 & 99.40984 & 0.110824 & 0.043839 & 0.419951 & 0.015548 \\
\hline 6 & 99.40983 & 0.110825 & 0.043839 & 0.419953 & 0.015548 \\
\hline 7 & 99.40982 & 0.110825 & 0.043839 & 0.419953 & 0.015563 \\
\hline 8 & 99.40981 & 0.110825 & 0.043839 & 0.419953 & 0.015569 \\
\hline 9 & 99.40981 & 0.110825 & 0.043839 & 0.419953 & 0.015575 \\
\hline 10 & 99.40980 & 0.110825 & 0.043839 & 0.419953 & 0.015580 \\
\hline
\end{tabular}

Table 9. Variance decomposition analysis of Gazprom Stocks

\begin{tabular}{llllcc}
\hline Period & Gazprom Stocks & Oil Price & LSE & Interest Rates & $\begin{array}{l}\text { Industrial } \\
\text { Production }\end{array}$ \\
\hline 1 & 100.0000 & 0.000000 & 0.000000 & 0.000000 & 0.000000 \\
2 & 99.70388 & 0.002207 & 0.000295 & 0.253707 & 0.039913 \\
3 & 99.34976 & 0.172296 & 0.047377 & 0.390748 & 0.039817 \\
4 & 99.33467 & 0.177760 & 0.047423 & 0.393651 & 0.046500 \\
5 & 99.33162 & 0.177766 & 0.047542 & 0.394717 & 0.048353 \\
6 & 99.32942 & 0.177780 & 0.047541 & 0.394710 & 0.050551 \\
7 & 99.32770 & 0.177784 & 0.047541 & 0.394716 & 0.052257 \\
8 & 99.32615 & 0.177786 & 0.047540 & 0.394716 & 0.053806 \\
9 & 99.32482 & 0.177787 & 0.047539 & 0.394715 & 0.055135 \\
10 & 99.32366 & 0.177788 & 0.047539 & 0.394715 & 0.056296 \\
\hline
\end{tabular}

Table 10. The ARCH Lagrange multiplier (LM) test for the oil stocks and oil price

\begin{tabular}{llll}
\hline Stocks & Exxon Mobil & Reliance Industries & Royal Dutch Shel \\
\hline Constant & & & \\
AR(1) & 0.000382 & 0.004377 & 0.000194 \\
Probability & 0.970257 & 0.977934 & 0.978343 \\
F-statistics & 0.0000 & 0.0000 & 0.0000 \\
Probability & 19614.06 & 28836.11 & 16065.04 \\
\hline
\end{tabular}

The null hypothesis is no ARCH.

All ARCH effects are significant at the 1\% level.

All variables are in logarithmic form

Table 11. Estimates of GJR GARCH

\begin{tabular}{llll}
\hline & Exxon Mobil & Reliance Industries & Royal Dutch Shell \\
\hline Mean equation & & & \\
Oil price & $0.620847^{*}$ & $1.863194^{*}$ & $0.515737^{*}$ \\
& $(248.7385)$ & $(205.7621)$ & $(258.2248)$ \\
Constant & $1.572677^{*}$ & $-4.895373^{*}$ & $1.282430^{*}$ \\
& $(161.2549)$ & $(-132.4518)$ & $(173.7750)$ \\
Variance equation & & & \\
Constant & $0.000160^{*}$ & $0.001117^{*}$ & $0.000124^{*}$ \\
& $(4.379959)$ & $(3.367979)$ & $(6.854251)$ \\
ARCH & $0.840256^{*}$ & $0.942672^{*}$ & $0.925324^{*}$ \\
& $(3.998672)$ & $(3.035662)$ & $(5.374756)$ \\
I(Dummy variable) & 0.029910 & 0.032610 & 0.011570 \\
& $(0.142617)$ & $(0.092621)$ & $(0.058585)$ \\
GARCH & 0.128752 & 0.046100 & 0.058918 \\
& $(1.533471)$ & $(0.993239)$ & 1.177387 \\
\hline
\end{tabular}


All variables are in logarithmic form. $Z$ statistics are in parentheses.

* Significant at the $1 \%$ level. **Significant at the $5 \%$ level. ***Significant at the $10 \%$ level.

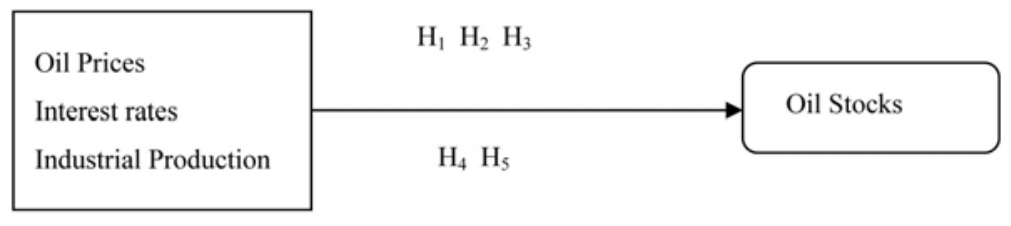

Figure 1. Theoretical Framework
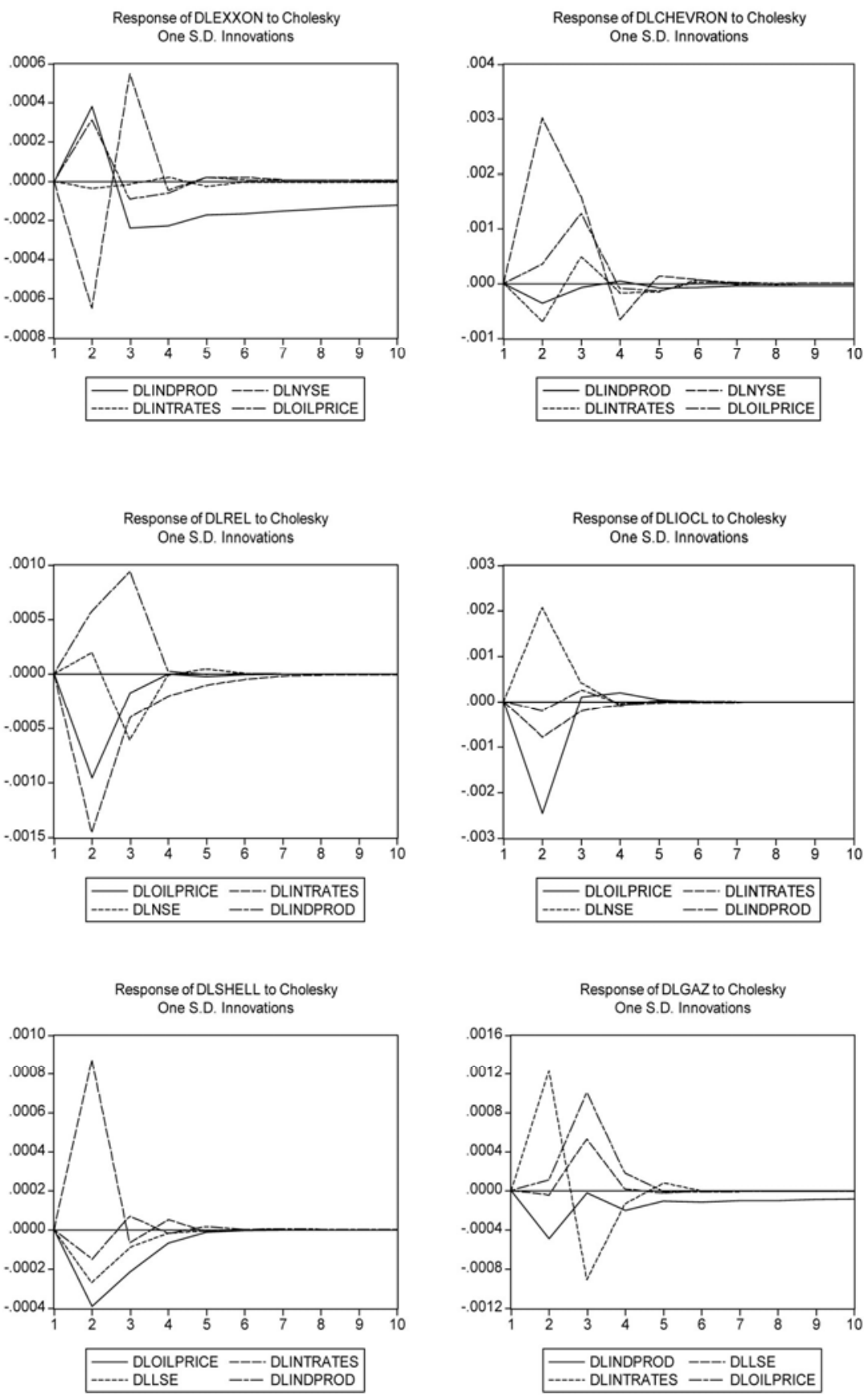

Figure 2. Impulse response of stocks 